\title{
Kandungan Logam Berat Cu (Tembaga) Dan Pb (Timbal) Pada Air Dan Sedimen Di Kawasan Industri Teluk Lampung, Provinsi Lampung
}

\section{Concentration Of Heavy Metal Cu (Copper) And Pb (Lead) In The Water And Sediments Of Industrial Area, Lampung Bay, Lampung Province}

\author{
Mutiara Ananda Dwi Permata, Anna Ida Sunaryo Purwiyanto* dan \\ Gusti Diansyah
}

\author{
IImu Kelautan, Fakultas Matematika dan IImu Pengetahuan Alam, Universitas Sriwijaya \\ Jl. Palembang-Prabumulih KM.32, Ogan Ilir, Sumatera Selatan 30662 Indonesia \\ *Email : anna_is_purwiyanto@unsri.ac.id
}

\begin{abstract}
ABSTRAK
Logam berat dalam suatu perairan dibutuhkan oleh makhluk hidup untuk berbagai proses metabolisme tetapi jika berlebihan akan menjadi racun. Logam berat $\mathrm{Cu}$ (tembaga) merupakan logam esensial sedangkan logam berat $\mathrm{Pb}$ (timbal) merupakan logam non esensial. Aktivitas-aktivitas di Teluk Lampung yang berpotensi menurunkan kualitas perairan adalah Pelabuhan Panjang, industri serta banyaknya pemukiman penduduk. Tujuan dari penelitian ini adalah menganalisis kandungan $\mathrm{Cu}$ dan $\mathrm{Pb}$ pada air dan sedimen serta menganalisis enrichment factor tembaga $(\mathrm{Cu})$ dan timbal $(\mathrm{Pb})$ pada sedimen. Penelitian ini dilakukan pada bulan April - Mei 2016. Metode yang digunakan adalah purposive sampling dengan analisis logam berat menggunakan SSA AA- 7000. Hasil penelitian menunjukan bahwa konsentrasi logam berat $\mathrm{Cu}(\mathrm{ttd}-0,008 \mathrm{mg} / \mathrm{l})$ dalam air masih memenuhi standar baku mutu $(<0,008 \mathrm{mg} / \mathrm{l})$ dan logam berat $\mathrm{Pb}$ (ttd-0,23 $\mathrm{mg} / \mathrm{l})$ secara umum telah melewati standar baku mutu $(<0,008 \mathrm{mg} / \mathrm{l})$. Berdasarkan kriteria baku mutu US-EPA, konsentrasi logam berat $\mathrm{Cu}$ dan $\mathrm{Pb}$ dalam sedimen masih memenuhi standar ( $\mathrm{Cu} 49,98 \mathrm{mg} / \mathrm{kg}$ dan $\mathrm{Pb} 47,82 \mathrm{mg} / \mathrm{kg}$ ). Berdasarkan kriteria baku mutu SEPA, secara umum untuk konsentrasi logam berat $\mathrm{Cu}(1,02-38,75 \mathrm{mg} / \mathrm{kg})$ telah melewati baku mutu $(15 \mathrm{mg} / \mathrm{kg})$ dan untuk logam berat $\mathrm{Pb}(15,41-32,66 \mathrm{mg} / \mathrm{kg})$ masih memenuhi standar baku mutu $(25 \mathrm{mg} / \mathrm{kg})$. Nilai enrichment factor $\mathrm{Pb}$ dan $\mathrm{Cu}$ pada perairan kawasan industri Teluk Lampung sumber berasal dari proses alam (kategori pengayaan minimal - cukup).
\end{abstract}

Kata kunci : baku mutu, enrichment factor, pengayaan

\begin{abstract}
Heavy metals in the waters needed by the organism in every metabolic processes, but if excessive it could be toxic. $\mathrm{Cu}$ is an essential metal while $\mathrm{Pb}$ is non-essential metal. Panjang Port, industries, and urbanization are some activities in Lampung Bay that potentially degraded the quality of the waters. The purpose of this research were to analyze the concentration of $\mathrm{Cu}$ and $\mathrm{Pb}$ in the waters and sediments and to determine the enrichment factors of $\mathrm{Cu}$ and $\mathrm{Pb}$ in the sediments. This research was conducted at AprilMay 2016. The method of this research was purposive sampling and heavy metals analyzed by using AAS AA-7000. The results showed that concentration of $\mathrm{Cu}$ (no detected-0,008 $\mathrm{mg} / \mathrm{I}$ ) in the waters was below the quality standard $(<0,008 \mathrm{mg} / \mathrm{l})$ while $\mathrm{Pb}$ (no detected $-0,23 \mathrm{mg} / \mathrm{l}$ ) in the waters generally exceed the quality standard $(<0,008 \mathrm{mg} / \mathrm{l})$. Based on US-EPA quality standard, the concentration of $\mathrm{Cu}$ and $\mathrm{Pb}$ in sediments were below the quality standard ( $\mathrm{Cu} 49,98 \mathrm{mg} / \mathrm{kg}$ and $\mathrm{Pb} 47,82 \mathrm{mg} / \mathrm{kg}$ ) while based in a quality standard using SEPA, the concentration of $\mathrm{Cu}(1,02-38,75 \mathrm{mg} / \mathrm{kg})$ in sediments generally were exceed $(15 \mathrm{mg} / \mathrm{kg})$ and $\mathrm{Pb}(15,41-32,66 \mathrm{mg} / \mathrm{kg})$ in sediments generally still below the quality standard (25 mg/kg). Based on the value of enrichment factor for $\mathrm{Cu}$ and $\mathrm{Pb}$ at industrial area in Lampung Bay, the source of heavy metals were enriched by natural process (category of minimal to significant of enrichment).
\end{abstract}

Keywords : quality standard, enrichment factor, enrichment

PENDAHULUAN

Logam berat dalam suatu perairan dibutuhkan oleh makhluk hidup untuk berbagai proses metabolisme tetapi jika logam berat tersebut berlebihan akan menyebabkan keracunan. Logam berat dikatakan sebagai bahan pencemar apabila 
keberadaanya melewati batas baku mutu (Palar, 2012). Keberadaan Logam berat juga tidak hanya ada berada pada perairan tetapi juga mengendap dalam sedimen dan biota. Menurut Rochyatun et al. (2006) logam berat juga akan terakumulasi dalam sedimen dan biota melalui proses gravitasi. Menurut Ali et al. (2013) secara umum logam berat alami masuk ke lingkungan dengan cara yaitu adanya pelapukan mineral, erosi serta aktivitas vulkanik. Jalur masuk logam berat dalam suatu perairan dapat berasal dari sumber-sumber alamiah dan juga dari aktivitas-aktivitas yang dilakukan oleh manusia.

Menurut Palar (2012) sumber alami logam berat $\mathrm{Cu}$ adalah dari pengkisan (erosi) dari batuan mineral dan debu-debu yang mengandung partikulat $\mathrm{Cu}$ di udara sedangkan sumber aktivitas manusia adalah industri, galangan kapal dan rumah tangga. Menurut Yanthy et al. (2013) salah satu sumber logam berat $\mathrm{Cu}$ yang berasal dari kegiatan rumah tangga adalah limbah dari cairan pembersih lantai yang mengandung CuO. Timbal $(\mathrm{Pb})$ masuk ke suatu perairan secara alami melalui pengkristalan timbal $\mathrm{Pb}$ ) di udara dengan bantuan air hujan serta proses korosifikasi dari batuan mineral akibat gelombang dan angin (Palar, 2012). Menurut Sudarmaji et al. (2006) sumber $\mathrm{Pb}$ yaitu berasal dari industri baterai, industri kabel dan industri kima serta hasil pembakaran bahan bakar kendaraan.

Penelitian terhadap kandungan logam berat $\mathrm{Cu}$ dan $\mathrm{Pb}$ di perairan kawasan industri Teluk Lampung pada air dan sedimen diperlukan untuk mengevaluasi seberapa besar pencemaran yang terjadi di daerah tersebut dan untuk mengetahui darimana sumber peningkatan konsentrasi logam berat tersebut pada sedimen yang dijadikan indikator dengan menggunakan standard quality guidelines yaitu enrichment factor.

\section{METODE PENELITIAN}

Penelitian mengenai Kandungan Logam Berat Tembaga ( $\mathrm{Cu}$ ) dan Timbal ( $\mathrm{Pb}$ ) pada Air dan Sedimen di Kawasan Industri Teluk Lampung Provinsi Lampung dilaksanakan pada tanggal 3 April 2016 dengan mengambil air dan sedimen di kawasan industri Teluk Lampung Provinsi Lampung (Gambar 1). Analisis kandungan logam berat pada sampel air dan sedimen telah dilaksanakan pada tanggal 2-19 Mei 2016 di Laboratorium Balai Riset dan Standardisasi (BARISTAND) Industri Palembang, Sumatera Selatan.

\section{Analisis Sampel Air}

Menurut SNI 6989.6:2009 untuk cara uji tembaga (Cu) dan SNI 6989.8.2009 untuk cara uji timbal $(\mathrm{Pb})$, analisis sampel air untuk logam berat tembaga $(\mathrm{Cu})$ dan timbal $(\mathrm{Pb})$ total dilakukan dengan cara homogenkan sampel air lalu diambil sebanyak $50 \mathrm{ml}$ dengan menggunakan gelas ukur masukan ke dalam gelas piala lalu ditambahkan $5 \mathrm{ml}$ HNO3 lalu ditutup dengan kaca arloji. Sampel dipanaskan perlahan-lahan sampai sisa volumenya $15-20 \mathrm{ml}$ dengan menggunakan hot plate. Sampel disaring menggunakan kertas saring 0,45 $\mu \mathrm{m}$. Sampel dipindahkan ke dalam labu ukur $50 \mathrm{ml}$ dan ditambahkan aquades sampai tepat tanda tera dan dihomogenkan. Sampel air siap diuji dalam Spektrofotometer Serapan Atom (SSA) AA7000 pada kisaran kadar logam tembaga (Cu) dan timbal $(\mathrm{Pb})$ dengan panjang gelombang $324,7 \mathrm{~nm}$, dan $283,3 \mathrm{~nm}$. Batas deteksi logam berat $\mathrm{Cu}$ dan $\mathrm{Pb}$ pada SSA AA7000 adalah $<0,003 \mathrm{mg} / \mathrm{l}$ dan $<0,01 \mathrm{mg} / \mathrm{l}$.

\section{Analisis Sampel Sedimen}

Menurut SNI 06-6992.5-2004 untuk cara uji tembaga (Cu), SNI 06-6992.3-2004 untuk cara uji timbal (Pb) dan SNI 066992.7-2004 untuk cara uji besi ( $\mathrm{Fe})$, analisis sampel sedimen dilakukan dengan cara dimasukan sampel sedimen dalam cawan petri, dikeringkan dalam oven suhu $105^{\circ} \mathrm{C}$ selama 24 jam dan dinginkan di desikator.

Sampel sedimen diambil sebanyak 5 gram kedalam gelas piala ditambahkan $25 \mathrm{ml}$ aquades. Sampel tersebut ditambahkan 10 $\mathrm{ml}$ asam nitrat (HNO3) diaduk hingga bercampur rata. Sampel dipanaskan menggunakan hot plate dengan suhu $1050 \mathrm{C}$ sampai volume $\pm 10 \mathrm{ml}$ lalu diangkat dan dinginkan. Sampel ditambahkan $5 \mathrm{ml}$ asam

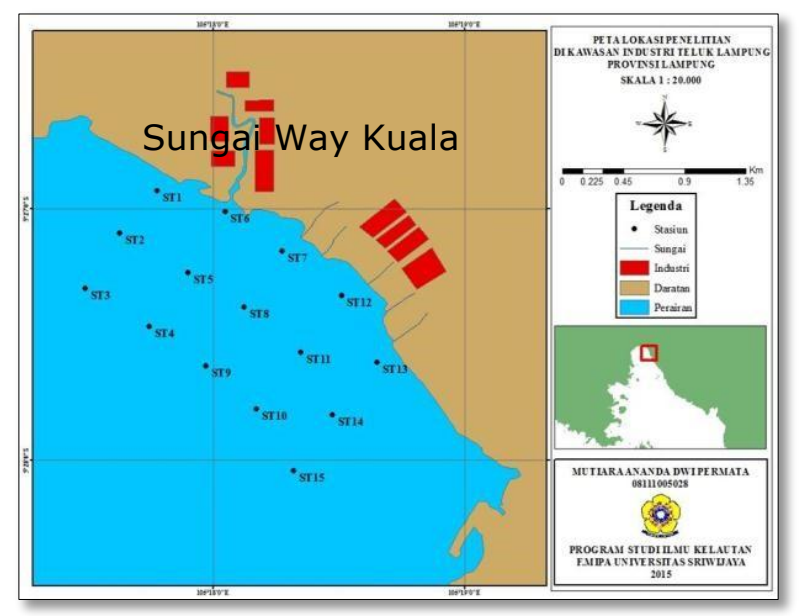

Gambar 1. Peta lokasi penelitian 
nitrat (HNO3) dan $3 \mathrm{ml}$ asam perklorat (HClO4). Sampel dipanaskan lagi sampai timbul asap putih dan larutan contoh uji menjadi jernih setelah itu pemanasan dilanjutkan selama \pm 30 menit. Sampel disaring menggunakan kertas saring 0,45 um.Sampel dipindahkan ke dalam labu ukur $50 \mathrm{ml}$ dan ditambahkan aquades sampai tepat tanda tera dan dihomogenkan. Sampel sedimen siap diuji dalam Spektrofotometer Serapan Atom (SSA)AA-7000 pada kisaran kadar logam tembaga $(\mathrm{Cu})$, timbal $(\mathrm{Pb})$ dan besi (Fe) dengan panjang gelombang 324,7 $\mathrm{nm}, 283,3 \mathrm{~nm}$ dan $248,3 \mathrm{~nm}$.

\section{Penentuan Kadar Air}

Penentuan kadar air pada sedimen dilakukan dengan cara cawan petri di timbang menggunakan timbangan analitik lalu ditambahkan sebanyak \pm 3 gr. Contoh uji dipanaskan pada oven dengan suhu $1050 C$ selama 2 jam setelah itu didinginkan dalam desikator. Contoh uji ditimbang dan dicatat. Penentuan kadar air menggunakan persamaan:

$$
\mathrm{Ka}=\frac{C s b-C s t}{C s b} \times 100 \%
$$

Dimana: $\mathrm{Ka}=$ kadar air (\%) ; $C s b=$ berat contoh uji sebelum dipanaskan $(\mathrm{g}) ; C s t=$ berat contoh uji setelah dipanaskan (berat kering) ( $g$ )

\section{Perhitungan Konsentrasi logam berat pada sedimen}

Perhitungan konsentrasi logam berat menggunakan persamaan:

$$
\text { Konsentrasi logam berat sebenarnya }=\frac{C x V \times f p}{B\left(1-\frac{k}{100}\right)}
$$

Dimana: $C=$ konsentrasi logam berat yang diperoleh dari kurva kalibrasi $(\mathrm{mg} / \mathrm{l}) ; V=$ volume akhir (I) ; $B=$ berat contoh uji $(\mathrm{kg})$; $K a=$ kadar air (\%)

\section{Analisis Data}

Analisis data dilakukan dengan melihat hasil pengukuran di laboratorium. hasil akan disajikan dalam bentuk grafik kemudian dijelaskan secara deskriptif. Kandungan logam berat $\mathrm{Cu}, \mathrm{Pb}$ dan parameter lingkungan pada air dibandingkan dengan Kriteria Baku Mutu Air Laut untuk Biota Laut berdasarkan Keputusan Menteri Lingkungan Hidup No 51 tahun 2004 sedangkan Cu dan $\mathrm{Pb}$ pada sedimen dibandingkan dengan Swedish Environmental Protection Agency (SEPA) 2000 Dan United States Environmental Protection Agency (US-EPA)
2004. Menggunakan faktor pengayaan (Enrichment Factors, EF). Faktor Pengayaan (Enrichment Factors, EF) dihitung dengan persamaan (Helz et al., 1983 dalam Rule, 1986):

$$
\mathrm{EF}=\frac{\left(\frac{\mathrm{Xs}}{\mathrm{As}}\right) \text { Sediment }}{\left(\frac{\mathrm{Xe}}{\mathrm{Ae}}\right) \text { Earth Crust }}
$$

Dimana: $X s=$ Konsentrasi logam sampel terukur disedimen yaitu $\mathrm{Cu}$ dan $\mathrm{Pb} ; A s=$ Konsentrasi logam referensi sampel terukur sedimen yaitu $\mathrm{Fe} ; \mathrm{Xe}=$ Konsentrasi logam sampel terukur di earth crust yaitu $\mathrm{Cu}$ dan $\mathrm{Pb}$ ; $A e=$ Konsentrasi logam referensi sampel terukur di earth crust yaitu $\mathrm{Fe}$

Kriteria nilai EF mengacu pada Sutherland (2000) dalam Hidayati et al. (2014) adalah sebagai berikut:

$1<\mathrm{EF}<2=$ Pengayaan minimal

$2 \leq \mathrm{EF}<-5=$ Pengayaan sedang (moderate) $5 \leq \mathrm{EF}<20=$ Pengayaan cukup (significant) $20 \leq \mathrm{EF}<40=$ Pengayaan tinggi (very high)

$\mathrm{EF}>40=$ Pengayaan sangat tinggi (extremely high)

\section{HASIL DAN PEMBAHASAN}

\section{Arus Perairan}

Rata-rata kecepatan arus permukaan di perairan kawasan industri Teluk Lampung adalah 0,15 m/s. Kecepatan arus paling kuat ditemukan pada stasiun 2 dan kecepatan arus paling lemah pada Stasiun 7 dan 10 (Gambar 2).

Pola arah arus pada permukaan perairan kawasan industri Teluk Lampung yakni cenderung dari laut menyisir bagian darat lalu mengarah ke laut lagi. Pola arah arus yang mengarah ke laut disebabkan karena pengambilan sampel dilakukan pada saat surut sehingga arus akan mengalir dari daratan ke arah lautan lepas. Menurut Pariwono (1999) pada saat air pasang, arus pada umunya akan mengalir dari lautan lepas ke arah pantai dan akan mengalir kembali ke arah semula pada saat air surut.

Rata-rata kecepatan arus dasar perairan kawasan industri Teluk lampung adalah 0,04 $\mathrm{m} / \mathrm{s}$. Kecepatan arus paling kuat pada stasiun 10 dan kecepatan arus paling lemah pada Stasiun 1, 2, 3, 8, 11 dan 12 (Gambar 3). Pola dan arah arus pada dasar perairan kawasan industri Teluk Lampung yakni arah arus cenderung ke arah laut menyisir pantai dan mengarah ke laut. Kecepatan arus pada permukaan lebih kuat dibandingkan dengan kecepatan arus pada dasar perairan. Hal ini 
menunjukkan bahwa kuatnya arus pada permukaan dibandingkan arus pada dasar ini disebabkan oleh permukaan air yang digerakkan oleh angin. Menurut Azis (2006) angin cenderung mendorong lapisan air di permukaan laut dalam arah gerakan angin akan tetapi karena pengaruh rotasi bumi maka arus tidak bergerak searah dengan arah angin. Sehingga kecepatan arus yang dibangkitkan angin akan semakin berkurang dengan bertambahnya kedalaman.

\section{Kandungan Logam Berat dalam Air}

Konsentrasi logam berat dalam air untuk tembaga ( $\mathrm{Cu}$ ) berkisar antara ttd$0,008 \mathrm{mg} / \mathrm{l}$. Sedangkan Pb berkisar antara ttd $-0,23 \mathrm{mg} / \mathrm{l}$. Batas deteksi SSA untuk logam berat $\mathrm{Pb} \quad(<0,01 \mathrm{mg} / \mathrm{l}) \quad$ (Gambar 4). Berdasarkan Keputusan Menteri Lingkungan Hidup No 51 Tahun 2004 bahwa batas

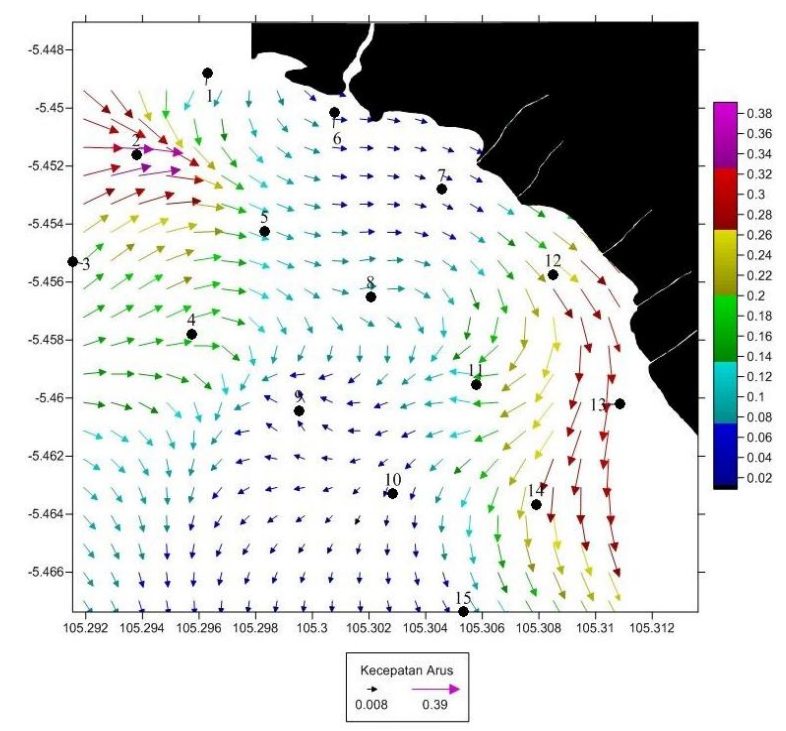

Gambar 2. Pola sebaran arus permukaan

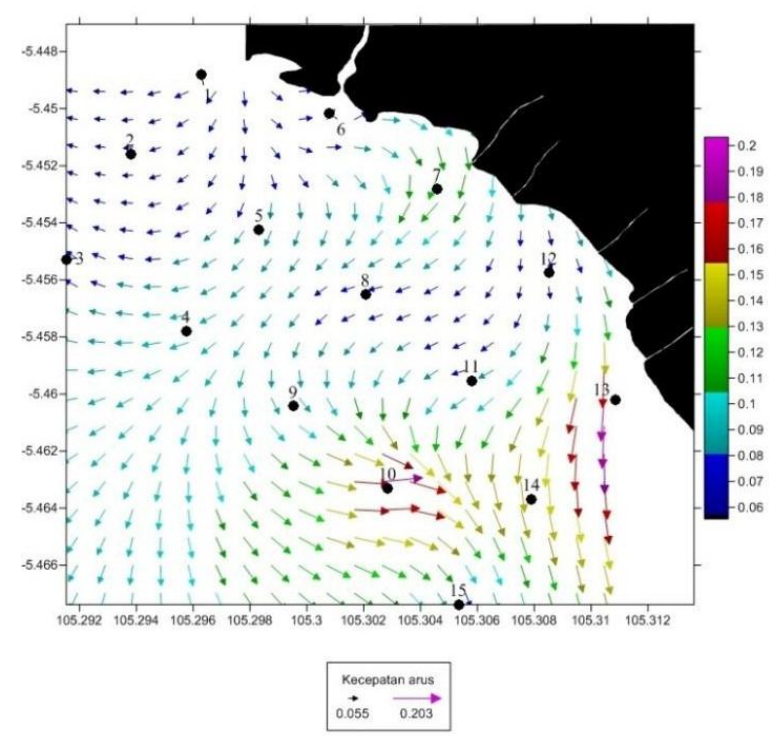

Gambar 3. pola sebaran arus dasar maksimal Cu di perairan yakni sebesar 0,008 $\mathrm{mg} / \mathrm{l}$. Konsentrasi $\mathrm{Cu}$ dalam air di perairan kawasan industri Teluk Lampung masih memenuhi kriteria baku mutu. Hal ini juga sesuai menurut Meneely et al. (1979) dalam Effendi (2003) kandungan logam tembaga pada perairan laut 0,001-0,025 $\mathrm{mg} / \mathrm{l}$.

Konsentrasi logam berat $\mathrm{Cu}$ terdeteksi pada Stasiun 8 dan 13 sedangkan untuk stasiun lainnya tidak terdeteksi. Tidak terdeteksinya logam berat $\mathrm{Cu}$ menujukkan bahwa kandungan logam $\mathrm{Cu}$ dalam air pada stasiun tersebut memiliki nilai yang kecil dan masih berada dibawah batas deteksi SSA $(0,003 \mathrm{mg} / \mathrm{l})$. Perbedaan kandungan logam berat $\mathrm{Cu}$ dalam air laut pada setiap stasiun diduga disebabkan oleh sumber logam berat Cu di dekat darat dan pola arus yang terjadi (Gambar 2). Tingginya kandungan logam berat $\mathrm{Cu}$ pada stasiun 13 diduga disebabkan oleh adanya pergerakan arus dari stasiun di dekat darat yang mendapatkan masukan dari sungai yang mengarah ke stasiun 13. Amin et al. (2011) menyatakan bahwa konsentrasi logam berat dalam air cenderung dipengaruhi oleh berbagai faktor seperti pola arus. Arus perairan dapat menyebarkan logam berat yang terlarut ke segala arah.

Konsentrasi logam berat $\mathrm{Pb}$ tertinggi berada pada stasiun 1 sedangkan yang tidak terdeteksi pada Stasiun 9, 12, 13,14 dan 15. Tingginya kandungan logam berat $\mathrm{Pb}$ pada Stasiun 1, 2, 3, 4, 5, 6, 7, 8 dibandingkan stasiun lainnya menunjukkan bahwa sumber logam berat tersebut diduga berasal masukan sungai pada saat surut.

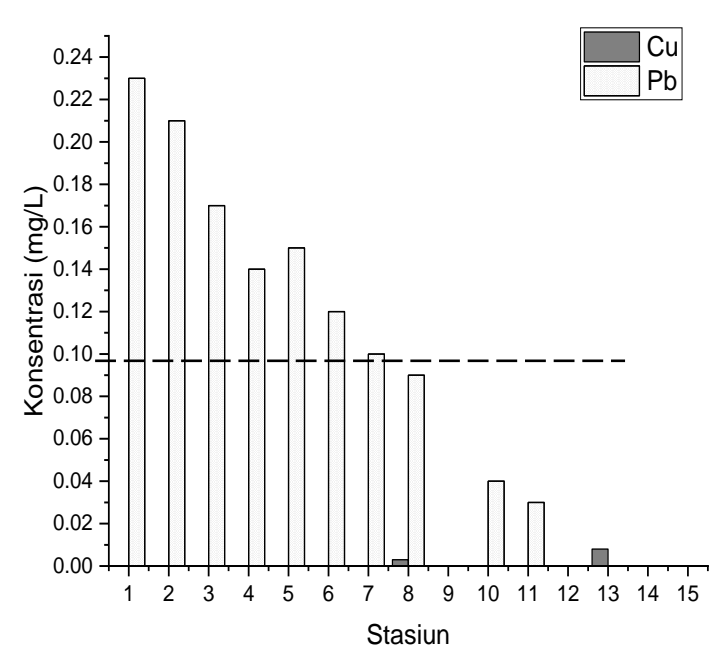

Gambar 4. Konsentrasi Logam Berat $\mathrm{Cu}$ dan $\mathrm{Pb}$ pada air

Keterangan :----- = Batas baku mutu KEPMEN LH No 51 tahun $2004(\mathrm{Cu}<0,008 \mathrm{mg} / \mathrm{l} ; \mathrm{Pb}<0,008$ $\mathrm{mg} / \mathrm{l})$ 
Adapun aktivitas industri yang berpotensi menghasilkan logam berat $\mathrm{Pb}$ adalah limbah semen, batubara, minyak dan pupuk. Menurut Suhartono (2011) Pb berasal dari pembakaran bahan bakar kendaraan bermotor sedangkan menurut Rochyatun et al. (2006) umumnya bahan bakar minyak mendapat zat tambahan tetraetyl yang mengandung $\mathrm{Pb}$. Suhariyono dan Menry (2003) menyatakan bahwa bahan baku semen mengandung unsur $\mathrm{Cu}, \mathrm{Ni}, \mathrm{Zn}$ dan $\mathrm{Pb}$. Menurut Keputusan Menteri Lingkungan Hidup No 51 Tahun 2004, bahwa ambang batas logam berat $\mathrm{Pb}$ yang diperbolehkan yakni sebesar 0,008 mg/l. Konsentrasi logam berat $\mathrm{Pb}$ pada air perairan kawasan industri Teluk Lampung yang memenuhi kriteria baku mutu adalah Stasiun 9, 12, 13, 14 dan 15 sedangkan untuk stasiun lainnya tidak memenuhi baku mutu.

Konsentrasi logam berat $\mathrm{Pb}$ lebih tinggi dibandingkan dengan $\mathrm{Cu}$. Hal ini disebabkan karena sifat dari logam berat $\mathrm{Cu}$ yang mudah terlarut dan mengendap dalam sedimen dibandingkan dengan $\mathrm{Pb}$. Menurut Hutagalung (1991) dalam Supriyantini dan Soenardjo (2015) kemampuan beberapa logam berat untuk mengendap pada sedimen sesuai urutan adalah $\mathrm{Hg}>\mathrm{Cu}>\mathrm{Ni}>\mathrm{Pb}>\mathrm{Co}>$ cd.

\section{Kandungan Logam Berat dalam Sedimen}

Konsentrasi logam berat $\mathrm{Cu}$ dalam sedimen memiliki berkisar 1,02 - 38,75 $\mathrm{mg} / \mathrm{kg}$ dengan rata-rata $16,25 \mathrm{mg} / \mathrm{kg}$. Konsentrasi logam berat $\mathrm{Cu}$ terendah berada pada (stasiun 15) sedangkan tertinggi pada (stasiun 6). Konsentrasi logam berat $\mathrm{Pb}$ dalam sedimen (Gambar 10) berkisar 15,41$32,66 \mathrm{mg} / \mathrm{kg}$ dengan rata-rata $21,74 \mathrm{mg} / \mathrm{kg}$. Konsentrasi logam berat $\mathrm{Pb}$ terendah berada pada stasiun 12 dan tertinggi pada stasiun 6 (Gambar 5).

Tingginya konsentrasi logam berat $\mathrm{Cu}$ pada stasiun 6 diduga karena mendapat masukan langsung dari Sungai Way Kuala yang memiliki banyak aktivitas industri. Adapun rendahnya konsentrasi logam berat $\mathrm{Cu}$ di stasiun 15 karena daerah ini terletak paling jauh dengan aliran Sungai Way Kuala. Berdasarkan baku mutu Swedish Environmental Protection Agency (SEPA) tahun $2000(15 \mathrm{mg} / \mathrm{kg}$ ) maka konsentrasi Cu dalam sedimen di perairan kawasan industri Teluk Lampung pada Stasiun 1-8 sudah melewati baku mutu adapun Stasiun 9-15 masih dibawah standar baku mutu. Menurut baku mutu United States Environmental Protection Agency (US-EPA) tahun 2004
$(49,98 \mathrm{mg} / \mathrm{kg})$ kandungan logam berat $\mathrm{Cu}$ dalam sedimen di perairan kawasan industri Teluk Lampung masih memenuhi standar baku mutu.

Tingginya konsentrasi logam berat $\mathrm{Pb}$ pada stasiun 6 diduga karena mendapatkan masukan dari Sungai Way Kuala. Jika dibandingkan dengan baku mutu Swedish Environmental Protection Agency (SEPA) tahun 2000 (25 mg/kg) maka yang sudah tidak memenuhi standar baku mutu yang telah di tetapkan (Stasiun 2, 5 dan 6) namun stasiun lainnya masih memenuhi baku mutu. Adapun berdasarkan baku mutu United States Environmental Protection Agency (USEPA) tahun $2004(47,82 \mathrm{mg} / \mathrm{kg})$ logam berat $\mathrm{Pb}$ dalam sedimen di perairan kawasan industri Teluk Lampung masih memenuhi standar baku mutu.

Tingginya kandungan logam berat $\mathrm{Pb}$ daripada logam berat $\mathrm{Cu}$ dalam sedimen diduga disebabkan karena limbah industri di sekitar daerah penelitian yang mayoritas terdapat industri yang dalam proses produksinya menggunakan logam berat $\mathrm{Pb}$. Contoh sumber logam berat $\mathrm{Pb}$ di daerah penelitian adalah industri semen, industri pupuk, industri batubara, pertamina dan industri kimia (Sudarmaji et al., 2006). Logam berat $\mathrm{Pb}$ memiliki berat atom yang lebih besar dibandingkan logam berat $\mathrm{Cu}$.

Selain itu, kandungan logam berat $\mathrm{Pb}$ dalam air juga lebih tinggi dibandingkan dengan logam berat $\mathrm{Cu}$. Menurut Anggraeny (2010) logam berat dengan berat atom yang lebih besar akan lebih cepat mengendap ke sedimen. Perbedaan kandungan logam berat

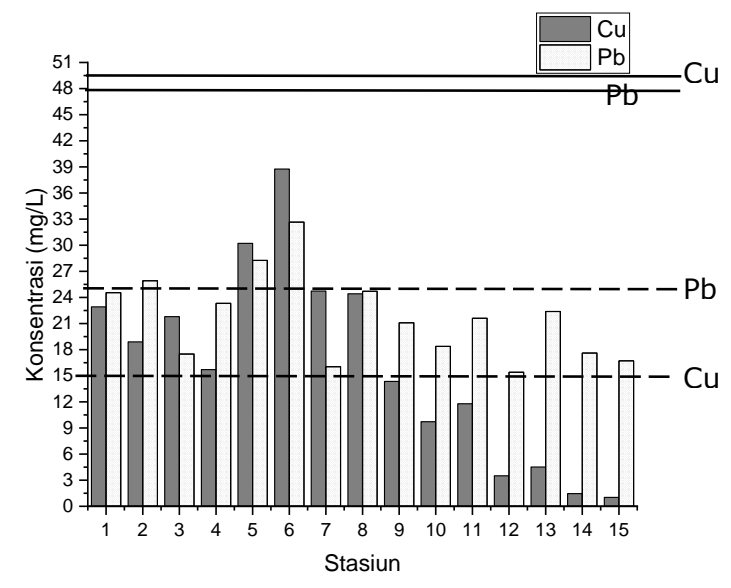

Gambar 5. Konsentrasi $\mathrm{Cu}$ dan $\mathrm{Pb}$ pada sedimen

Keterangan :

---- = Batas baku mutu SEPA $(\mathrm{Cu}<15 \mathrm{mg} / \mathrm{kg}$; $\mathrm{Pb}<25 \mathrm{mg} / \mathrm{kg}$ )

$=$ Batas baku mutu US-EPA $(\mathrm{Cu}<49,98$ $\mathrm{mg} / \mathrm{kg} ; \mathrm{Pb}<47,82 \mathrm{mg} / \mathrm{kg}$ ) 
dalam sedimen lebih besar dibandingkan kandungan logam berat pada air disebabkan oleh adanya akumulasi logam berat dalam sedimen. Darmono (2001) menyatakan bahwa logam berat yang mencemari air akan mengendap di dasar perairan dan mempunyai waktu tinggal (residence time) sampai ribuan tahun. Selain itu logam berat juga akan masuk kedalam tubuh makhluk hidup melalui proses bioakmulasi dan biomagnifikasi.

Logam berat yang masuk ke dalam lingkungan perairan akan mengalami pengendapan, pengenceran dan dispersi, kemudian diserap oleh organisme yang hidup di perairan tersebut. Pengendapan logam berat di suatu perairan terjadi karena adanya reaksi anion karbonat, hidroksil dan klorida. Logam berat mempunyai sifat yang mudah mengikat bahan organik dan mengendap di dasar perairan dan berikatan dengan partikelpartikel sedimen, sehingga konsentrasi logam berat dalam sedimen lebih tinggi dibandingkan dalam air. Logam berat dalam air akan berpindah ke dalam sedimen jika berikatan dengan materi organik bebas atau materi organik yang melapisi permukaan sedimen dan penyerapan langsung oleh permukaan sedimen (Hutagalung, 1991 dalam Bangun, 2005).

\section{Enrichment Factor (EF)}

Groengroeft (1998) dalam Amin et al. (2009) menyatakan bahwa enrichment factor
(EF) atau faktor pengayaan digunakan untuk mengevaluasi tingkat pencemaran pada sedimen di suatu ekosistem perairan serta suatu alat yang baik untuk membedakan antara logam yang berasal dari aktivitas antropogenik dengan yang berasal dari sumber alami. Nilai EF logam $\mathrm{Cu}$ dan $\mathrm{Pb}$ dapat dilihat pada Tabel 1.

Nilai enrichment factor (EF) (Tabel 1) untuk $\mathrm{Cu}$ berkisar 0,054 - 2,784 yaitu temasuk dalam kategori pengayaan minimal hingga pengayaan cukup. Kriteria nilai EF untuk logam berat $\mathrm{Cu}$ pada Stasiun 1,2,4-15 termasuk pada kriteria pengayaan minimal sedangkan stasiun 3 termasuk pada kriteria pengayaan sedang. Nilai rata-rata EF untuk $\mathrm{Cu}$ pada perairan kawasan industri Teluk Lampung adalah 0,866 yang termasuk dalam kategori pengayaan minimal.

Nilai EF untuk logam berat $\mathrm{Pb}$ pada perairan kawasan industri Teluk Lampung berkisar dari 3,036 - 9,832 yaitu temasuk dalam kategori pengayaan sedang hingga pengayaan cukup. Kriteria nilai EF untuk logam berat $\mathrm{Pb}$ pada Stasiun 1,2,4,5, 7, 8, 13-15 termasuk kriteria sedang dan Stasiun 3, 6, 9-12 termasuk dalam kriteria cukup.

Nilai EF untuk logam berat $\mathrm{Pb}$ pada perairan kawasan industri Teluk Lampung yaitu 5,106 untuk kategori pengayaan cukup. Berdasarkan interpretasi yang dikemukakan oleh Al-momani (2003) dalam Tahir et al. (2007), secara umum nilai EF di kawasan industri Teluk Lampung untuk $\mathrm{Cu}$

Tabel 1. Enrichment Factor (EF) $\mathrm{Cu}$ dan $\mathrm{Pb}$ pada sedimen

\begin{tabular}{ccccl}
\hline \multirow{2}{*}{ St } & \multicolumn{3}{c}{ Cu } & \multicolumn{1}{c}{ Pb } \\
\cline { 2 - 5 } & EF & \multicolumn{1}{c}{ Kategori } & EF & \multicolumn{1}{c}{ Kategori } \\
\hline 1 & 0,964 & Pengayaan minimal & 4,543 & pengayaan sedang \\
2 & 0,695 & Pengayaan minimal & 4,200 & pengayaan sedang \\
3 & 2,784 & pengayaan sedang & 9,832 & pengayaan cukup \\
4 & 0,623 & Pengayaan minimal & 4,072 & pengayaan sedang \\
5 & 1,196 & pengayaan minimal & 4,921 & pengayaan sedang \\
6 & 1,769 & pengayaan minimal & 6,560 & pengayaan cukup \\
7 & 1,064 & pengayaan minimal & 3,036 & pengayaan sedang \\
8 & 0,844 & Pengayaan minimal & 3,757 & pengayaan sedang \\
9 & 0,855 & Pengayaan minimal & 5,526 & pengayaan cukup \\
10 & 0,622 & Pengayaan minimal & 5,172 & pengayaan cukup \\
11 & 0,967 & Pengayaan minimal & 7,795 & pengayaan cukup \\
12 & 0,328 & Pengayaan minimal & 6,347 & pengayaan cukup \\
13 & 0,161 & Pengayaan minimal & 3,507 & pengayaan sedang \\
14 & 0,064 & Pengayaan minimal & 3,427 & pengayaan sedang \\
15 & 0,054 & Pengayaan minimal & 3,893 & pengayaan sedang \\
\hline Rerata & 0,866 & Pengayaan minimal & 5,106 & Pengayaan cukup \\
\hline
\end{tabular}



dikategorikan sebagai kawasan yang mengalami pengayaan minimal. Artinya logam $\mathrm{Cu}$ dianggap belum mengalami pengayaan karena sumber logam berat $\mathrm{Cu}$ dominan berasal dari kerak bumi. Adapaun nilai EF untuk $\mathrm{Pb}$ dikategorikan sebagai kawasan yang mengalami pengayaan cukup. Artinya logam dianggap tidak diperkaya karena komposisi logam berat sampel dengan alam tidak jauh berbeda. Zhang dan Liu (2002) dalam Amin et al. (2009) jika nilai EF $<1,5$ menunjukkan bahwa sumber logam berat lebih banyak berasal dari proses alami sedangkan jika nilai EF $>1,5$ adanya sumber logam berat dari aktivitas antropogenik. Sedangkan menurut Selvaraj et al. (2004) dalam Moore et al. (2009) jika nilai EF 0 $<10$ termasuk kedalam indikasi bahwa suatu perairan tersebut terjadi pengayaan berasal dari alam (kerak) atau daerah itu sendiri sedangkan jika nila EF >10 telah dianggap terjadi pengayaan dari sumber antropogenik. $\mathrm{Hal}$ ini menunjukkan bahwa EF pada penelitian ini merupakan pengayaan dari sumber alam.

\section{KESIMPULAN}

Berdasarkan penelitian, dapat disimpulkan bahwa kandungan $\mathrm{Cu}$ di perairan Kawasan Industri Teluk Lampung masih memenuhi standar baku mutu namun telah melewati standar baku mutu untuk logam $\mathrm{Pb}$. Logam $\mathrm{Cu}$ dan $\mathrm{Pb}$ pada sedimen masih berada di bawah standar baku mutu. Nilai enrichment factor $\mathrm{Pb}$ dan $\mathrm{Cu}$ pada perairan kawasan industri Teluk Lampung termasuk pada kategori pengayaan minimal sampai cukup yang artinya sumber logam berat berasal dari proses alam.

\section{REFERENSI}

Ali, H., Khan, E. \& Sajad, M.A. 2013. Phytoremediation of Heavy MetalsConcepts and Applications. J. Chemosphere. 869-881

Amin, B., Afriyani, E., Saputra, M.A. 2011. Distribusi Spasial Logam $\mathrm{Pb}$ dan $\mathrm{Cu}$ pada Sedimen dan Air Laut Permukaan di Perairan Tanjung Buton Kabupaten Siak Provinsi Riau. J. Teknobiologi. II(1): $1-8$

Anggraeny, Y.A. 2010. Analisis Kandungan Logam Berat $\mathrm{Pb}, \mathrm{Cd}$, dan $\mathrm{Hg}$ pada Kerang Darah (Anadara granosa) di Perairan Bojonegara, Kecamatan Bojonegara, Kabupaten Serang. [Skripsi]. Bogor: Fakultas Perikanan dan Ilmu Kelautan, Institut Pertanian Bogor. 55 hal

Azis, M.F. 2006. Gerak Air Dilaut. J. Oseana XXXI(4):9-21

Bangun, J.M. 2005. Kandungan Logam Berat Timbal (Pb) dan Kadmium (Cd) dalam Air, Sedimen dan Organ Tubuh Ikan Sokang (Triacanthus nieuhofi) di Perairan Ancol, Teluk Jakarta. [Skripsi]. Fakultas Perikanan dan Ilmu Kelautan, Institut Pertanian Bogor. 43 hal

Darmono. 2001. Lingkungan Hidup dan Pencemaran: Hubungan dengan Toksikologi Senyawa Logam. Jakarta: Universitas Indonesia (UI-Press). 179pp

Hidayati, N.V., Siregar, A.S., Sari, L.K., Putra, G.L., Hartono, Nugraha, I.P. \& Syakti, A.D. 2014. Pendugaan Tingkat Kontaminasi Logam Berat $\mathrm{Pb}, \mathrm{Cd}$ dan $\mathrm{Cr}$ pada Air dan Sedimen di Perairan Segara Anakan, Cilacapan. J. OmniAkuatika XIII(18):3039

Moore, F., Forghani, G., Qishlaqi, A.A., 2009, Assesment of Heavy Metal Contamination in Water and Surface Sediments of The Maharlu Saline Laku, SW Iran. Iranian J. Sci, Technol, Transact. 33(1):43-55

Palar, H. 2012. Pencemaran dan Toksikologi Logam Berat. Jakarta: Rineka Cipta. 152 hal

Pariwono, J. I. 1999. Kondisi Oseanografi Perairan Pesisir Lampung. BAPPENAS, Jakarta: IV:24.

Rochyatun, E., M. T. Kaisupy, A. Rozak. 2006. Distribusi Logam Berat dalam Air dan Sedimen di Perairan Muara Sungai Cisadane. Makara Sains 10(1): 35-40

Rule, J.H. 1986. Assessment of Trance Element Geochemistry of Hampton Roads Harbor and Lower Chesapeake Bay Area sediment. Environ. Geol. Water Sci. 8(4):209-219

[SEPA] Swedish Environmental Protection Agency. 2000. Environmental Quality Criteria Coasts and Seas. Sweden: Aralia

[SNI] Standar Nasional Indonesia 066992.3:2004. Cara Uji Timbal (Pb) secara Destruksi Asam dengan Menggunakan Spektrofotometer Serapan Atom (SSA) . Jakarta: Badan Standarisasi Nasional

[SNI] Standar Nasional Indonesia 066992.5:2004. Cara Uji Tembaga (Cu) secara Destruksi Asam dengan Menggunakan Spektrofotometer Serapan Atom (SSA). Jakarta: Badan Standarisasi Nasional 
[SNI] Standar Nasional Indonesia 066992.7:2004. Cara Uji Besi (Fe) secara Destruksi Asam dengan Menggunakan Spektrofotometer Serapan Atom (SSA). Jakarta: Badan Standarisasi Nasional.

[SNI] Standar Nasional Indonesia 6989.6:2009. Air dan Air Limbah Bagian 6: Cara Uji Tembaga (Cu) Secara Spektrofotometer Serapan Atom (SSA) Nyala. Jakarta: Badan Standarisasi Nasional

[SNI] Standar Nasional Indonesia 6989.8:2009. Air dan Air Limbah Bagian 8: Cara Uji Timbal (Pb) Secara Spektrofotometer Serapan Atom (SSA) -Nyala. Jakarta: Badan Standarisasi Nasional

Sudarmaji, Mukono, J. \& Corie, I.P. 2006. Toksikologi Logam Berat B3 dan Dampaknya terhadap Kesehatan. J Kes. Ling. 2(2):129-142

Suhariyono, G. \& Menry, Y. 2003. Ananlisis Logam Berat dalam Debu Udara Daerah Pemukiman Penduduk di Sekitar Pabrik Semen, Citeureup Bogor. Seminar APISORA-P3TIR BATAN

Suhartono, I.G.N. 2011. Limbah Kimia dalam Pencemaran Udara dan Air. Yogyakarta: Penerbit Andy Yogyakarta. 518 hal
Supriyantini, E., Soenardjo, N. 2015. Kandungan Logam Berat Timbal (Pb) dan Tembaga $(\mathrm{Cu})$ pada Akar dan Buah Mangrove Avicennia marina di Perairan Tanjung Emas Semarang. J. Kel. Trop. 18(2):98-106

Tahir, N.M., P.S. Chee, M. Jaafar. 2007. Determination of Heavy Metals Content In Soils and Indoor Dusts from Nurseries in Dungu, Terengganu. The Malaysian Analyt. Sci. 11(1):280-286

[US-EPA] United States Environmental Protection Agency. 2004. The Incidence and Severity of Sediment Contamination in Surface Waters of the United States, National Sediment Quality Survey : Second Edition. Washington Dc: Standards and Health Protection Division.

Yanthy, K.I., E. Sahara, K.S.P. Dewi. 2013. Spesiasi dan Bioavabilitas Logam Tembaga (Cu) pada Berbagai Ukuran Partikel Sedimen di Kawasan Pantai Sanur. Jurnal Kimia. 7(2):141-152 